DOI: http://dx.doi.org/10.1590/S0104-64972015002312

\title{
Temporal variation of the gammaridean fauna (Crustacea, Amphipoda) associated with the sponge Mycale angulosa (Porifera, Demospongiae) in southeastern Brazil
}

\author{
Mariana Fernandes de Britto Costa, Karine Ferreira Ribeiro Mansur and Fosca Pedini Pereira Leite* \\ (MFBC, KFRM, FPPL) Pós-Graduação em Biologia Animal, Instituto de Biociências, Unicamp, CP \\ 6109, 13083-970, Campinas, São Paulo, Brazil. E-mails: (MFBC) maricostta@gmail.com; (KFRM) \\ karinefrmansur@gmail.com; (FPPL) fosca@unicamp.br. *Corresponding author
}

\begin{abstract}
Marine sponges are advantageous microhabitats because of their complex architecture. The system of internal canals provides circulation of water and deposition of particulate organic matter, ensuring availability of food and shelter. Diminutive amphipods have little difficulty penetrating the spaces of sponges and remain in their aquiferous systems as one of the most abundant taxa in this association. This study evaluated the temporal variation of the gammaridean amphipod species associated with the sponge Mycale angulosa. Sponge samples were collected every three months over one year at Pontal da Cruz Beach, São Sebastião Channel, southeastern Brazil. The amphipod assembly varied over time, while the amphipod density and sponge biomass remained approximately constant. Six species contributed to the temporal variation infaunal composition, highlighting the importance of the natural history of each species.
\end{abstract}

Key words: Macrofauna, Gammaridea, Ecological assembly, Biological substrate, São Sebastião Channel.

\section{INTRODUCTION}

Marine sponges shelter many organisms that show commensal, mutual and even parasitic relationships with their host (Biernbaum, 1981). The fauna associated with sponges is sheltered from potential predators (Dalby, 1996; Huang et al., 2008; Fiore and Jutte, 2010) and adverse abiotic factors (Frith, 1976). Sponges may provide a feeding site for their associated fauna, since the circulation of water in the internal canals of the sponge results in deposition of particulate material, a source of food for many animals (Oshel and Steele, 1985; Crowe and Thomas, 2002; Ribeiro et al., 2003; Lörz and De Broyer, 2004). Sponges provide a habitat for groups with varied life histories and feeding habits, including Nematoda, Polychaeta, Pycnogonida, Amphipoda, Decapoda and Ophiuroidea (Biernbaum, 1981; Voultsiadou-Koukoura et al., 1987; Duarte and Nalesso, 1996; Ribeiro et al., 2003), but polychaetes and crustaceans are the most frequent inhabitants (Abdo, 2007; Stofel et al., 2008; Fiore and Jutte, 2010).

The sponge-associated fauna may be influenced by both environmental factors and host substrate parameters. Variations in sponge structure, such as size, texture, and external and internal morphology (Voultsiadou-Koukoura et al., 1987; Klitgaard, 1995; Neves and Omena, 2003), provide refuge to associated fauna (Huang et al., 2008). The availability and complexity of the host's internal canal system can affect the composition, diversity and abundance of the endofauna, which are dependent on the available internal space (Morgado and Tanaka, 2001; Abdo, 2007).

Among the groups associated with the sponge, amphipods are especially prominent for their species abundance and richness (Biernbaum, 1981; Stofel et al., 2008), represented mainly by the families Corophiidae, Melitidae, Leucothoidae and Colomastigidae (Thiel, 2000; Ribeiro et al., 2003; Thomas and Klebba, 2007). Some species of these families may be more common 
in sponges than in other substrates, such as Colomastigidae (Winfield and Ortiz, 2010), but many are present in other biological substrates such as algae (Jacobucci et al., 2009) and tunicates (Voultsiadou-Koukoura et al., 2007).

Mycale angulosa is a common sponge species along the northern coast of São Paulo; it is encrusting, thick (0.5-6 cm thick), and displays a large number of oscula with diameters usually between 1 and $10 \mathrm{~mm}$ on its surface (Muricy and Hajdu, 2006), which allow entry by many smallsized endobiontic animals.

This study evaluated the temporal variation of species of gammaridean amphipods associated with $M$. angulosa. An attempt was made to evaluate whether temporal variations in $M$. angulosa biomass during the study period affected the density and composition of the gammaridean fauna.

\section{MATERIAL AND Methods}

\section{Study area}

Samples were collected from pilings of the pier at Pontal da Cruz Beach. The beach is located on the São Sebastião Channel (Fig. 1), São Paulo, Brazil, where there are many fouling organisms, including Mycale angulosa and other sponge species.
Sampling

Samples of $M$. angulosa were collected by freediving every three months from May 2011 to March 2012. Samples were taken randomly from the submerged part of each of three different pilings by scraping with a spatula to remove an entire sponge. No pilings were repeated in consecutive samplings. The samples were placed in individual cloth bags with $0.02 \mathrm{~mm}$ mesh to prevent the associated fauna from escaping, and were transported to the laboratory, where they were kept in a freezer until triaging.

\section{Laboratory analysis}

In the laboratory, after thawing, each sponge sample was dissected under a stereomicroscope and its fauna carefully removed. The amphipods were identified to species level whenever possible. All individuals of each species were preserved in $70 \%$ ethanol.

After this procedure, the sponge biomass (as dry mass) was obtained in order to relate it to the amphipods. The sponges were dried in an oven for $42 \mathrm{~h}$ at $70{ }^{\circ} \mathrm{C}$, and then weighed on a precision balance to the nearest $0.0001 \mathrm{~g}$. The data were used to determine the density of associated animals (ind $\mathrm{g}^{-1}$ of sponge dry mass).

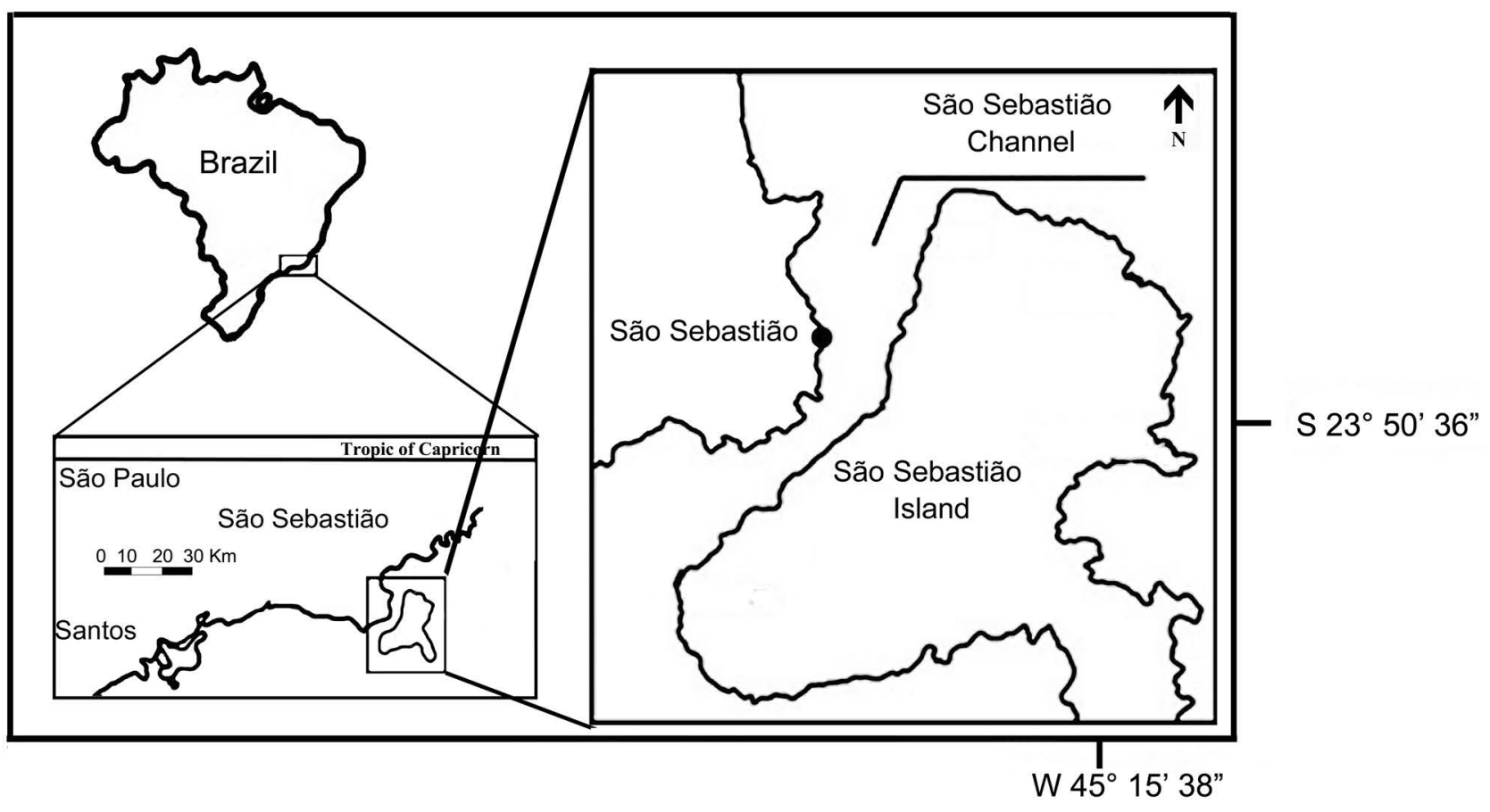

Figure 1. Northern coast of the State of São Paulo, showing the São Sebastião Channel and the sampling location (black dot). 


\section{Statistical analysis}

The amphipod density and sponge biomass were compared among the sampling months, using one-way ANOVA (Zar, 1996).

To compare the species composition of the amphipod assemblies among sampling periods, a multivariate permutation analysis of variance (PERMANOVA) was used. The density of the species (ind $\mathrm{g}^{-1}$ of sponge dry mass) was used to construct a similarity matrix using the Bray-Curtis distance. The PERMANOVA was done with 999 permutations (Anderson, 2001), followed by $a$ posteriori pair wise comparison test, to evaluate the contribution of the sampling months to the differences in the species composition. To assess the possibility of a pattern of differences among the sponges regarding amphipod composition, an nMDS analysis was done from the Bray-Curtis similarity matrix used previously. In addition, to investigate which amphipod species contributed most to the dissimilarity in faunal composition among the sampling periods, a SIMPER test (Clarke and Warwick, 1994) was used, from the same matrix.

\section{RESULTS}

In the study period, 11,525 amphipods associated with Mycale angulosa were collected, of which 4,196 were juveniles and were not included in the analysis. Nineteen species were identified, and occurred in different densities (Tab. 1).

The mean amphipod density (ind $\mathrm{g}^{-1}$ of sponge dry mass) was high in all months and did not differ significantly among the sampling periods $(\mathrm{F}=0.85, \mathrm{p}=0.64)$ (Fig. 2$)$. The mean sponge biomass was also similar during the year, with no significant differences $(\mathrm{F}=0.097, \mathrm{df}=3, \mathrm{p}=$ $0.96)$. However, marked variations in biomass of the three sponge samples were observed in each month (Fig. 3).

The composition of the amphipod assembly differed significantly among sampling months ( $\mathrm{F}$ $=1.71, \mathrm{p}=0.026)$ (Tab. 2). However, a definite period of time responsible for this differentiation could not be detected (Tab. 3). A non-metric multidimensional scaling (nMDS) showed that the species composition was similar in most months (Fig. 4). The similarity analysis (SIMPER) identified six species that contributed to the differences (Tab. 4 and Fig. 5). Monocorophium sp. reached a high density in May, and Dulichiella anisochir and Gammaropsis sophiae increased markedly in March. In addition, the slight increase of Stenothoe sp. in August combined with its low densities in other months, and the high densities of Photis longicaudata and Podocerus fissipes throughout the year should be considered (Fig. 5).

\section{Discussion}

Our study showed that the sponge Mycale angulosa is an important biological substrate for amphipods. These crustaceans may reach high densities and dominate the fauna associated with different sponge species (Frith, 1976; Ribeiro et al., 2003; Amsler et al., 2009; Schejter et al., 2012) near $100 \mathrm{~m}$ depth, in the Argentine Sea was studied. However, Duarte and Nalesso (1996) observed the marked dominance of polychaetes and ophiuroids in Zygomycale parishii (= $M$. angulosa) on different beaches on the São Paulo coast, Lamberto Beach in Ubatuba and Araça Beach in São Sebastião.

The differences between the fauna in the sponges from these three locations may be related to environmental factors, such as suspended sediment and anthropogenic contamination (organic contaminants, polychlorinated biphenyl (PCB) contaminants and heavy metals) (Roberts et al., 2008), and to morphological features of the sponge. Contaminant substances directly affect sponges, which for this reason are frequently used as bioindicators in marine environments (Gochfeld et al., 2007; Roberts et al., 2008). A rich fauna of invertebrates, including suspension-feeding and tube-dwelling herbivorous amphipods that might be affected by contaminants (Poore and Steinberg, 1999) inhabits sponges. There may be differences in contamination among the sites where these sponges were collected in the two studies. These differences may be related to the presence of the oil terminal located in the São Sebastião Channel, and to heavy traffic of ships and tourist boats, which may contaminate the water and sediment with heavy metals and petroleum hydrocarbons (ZanardiLamardo et al., 2013). In addition, there is high organic contamination in Araçá Bay, also situated in São Sebastiāo (Amaral et al., 2010). Contaminated biological substrates may influence both the habitat and feeding habits of the fauna, thus directly 
Table 1. Total number $(\mathrm{N})$, mean and standard deviation $( \pm$ ) of gammaridean amphipod species associated with the sponge Mycale angulosa from May/2011 to March/2012.

\begin{tabular}{|c|c|c|c|c|c|c|c|c|}
\hline \multirow[b]{2}{*}{ Species } & \multicolumn{2}{|c|}{ May/2011 } & \multicolumn{2}{|c|}{ August/2011 } & \multicolumn{2}{|c|}{ December/2011 } & \multicolumn{2}{|c|}{ March/2012 } \\
\hline & $\mathrm{N}$ & $\begin{array}{c}\text { Density } \\
\text { (ind./ } / \mathrm{g}^{-1} \text { sponge) }\end{array}$ & $\mathrm{N}$ & $\begin{array}{c}\text { Density } \\
\text { (ind./ } / \mathrm{g}^{-1} \text { sponge) }\end{array}$ & $\mathrm{N}$ & $\begin{array}{c}\text { Density } \\
\text { (ind. } / \mathrm{g}^{-1} \text { sponge) }\end{array}$ & $\mathrm{N}$ & $\begin{array}{c}\text { Density } \\
\text { (ind./g } / \mathrm{g}^{-1} \text { sponge) }\end{array}$ \\
\hline Ampithoe ramondi & 3 & $0.1( \pm 0.2)$ & 4 & $0.1( \pm 0.1)$ & 0 & -- & 0 & -- \\
\hline Batea catharinensis & 9 & $0.4( \pm 0.6)$ & 0 & --- & 0 & --- & 0 & -- \\
\hline Colomastix sp. & 19 & $0.8( \pm 0.7)$ & 1 & --- & 5 & $0.2( \pm 0.4)$ & 33 & $1.5( \pm 1.9)$ \\
\hline Monocorophium sp. & 800 & $22.6( \pm 15.7)$ & 60 & $2.0( \pm 0.9)$ & 162 & $6.5( \pm 6.4)$ & 212 & $6.8( \pm 4.0)$ \\
\hline Dulichiella anisochir & 64 & $1.9( \pm 1.3)$ & 45 & $1.3( \pm 2.0)$ & 191 & $6.5( \pm 10.3)$ & 334 & $15.1( \pm 16.9)$ \\
\hline Ericthonius punctatus & 66 & $1.8( \pm 1.7)$ & 70 & $2.1( \pm 1.9)$ & 28 & $0.9( \pm 0.3)$ & 230 & $6.4( \pm 5.0)$ \\
\hline Elasmopus brasiliensis & 3 & $0.04( \pm 0.1)$ & 48 & $1.6( \pm 1.8)$ & 51 & $1.7( \pm 0.9)$ & 96 & $1.6( \pm 2.2)$ \\
\hline Elasmopus pectenicrus & 17 & $0.8( \pm 0.8)$ & 6 & $0.2( \pm 0.3)$ & 1 & $0.03( \pm 0.1)$ & 1 & $3.0( \pm 0.1)$ \\
\hline Elasmopus rapax & 6 & $0.1( \pm 0.2)$ & 1 & -- & 0 & -- & 0 & -- \\
\hline Gammaropsis sophiae & 83 & $2.1( \pm 0.7)$ & 123 & $4.1( \pm 1.8)$ & 111 & $4.3( \pm 3.2)$ & 412 & $13.7( \pm 5.3)$ \\
\hline Gammaropsis togoensis & 65 & $1.4( \pm 0.8)$ & 107 & $3.7( \pm 5.0)$ & 2 & $0.1( \pm 0.1)$ & 8 & $0.4( \pm 0.7)$ \\
\hline Jassa slatteryi & 1 & $0.1( \pm 0.1)$ & 9 & $0.3( \pm 0.4)$ & 3 & $0.1( \pm 0.1)$ & 0 & --- \\
\hline Lembos hypacanthus & 3 & $0.1( \pm 0.1)$ & 74 & $2.4( \pm 2.5)$ & 72 & $2.7( \pm 2.3)$ & 38 & $1.2( \pm 0.2)$ \\
\hline Quadrimaera miranda & 8 & $0.3( \pm 0.3)$ & 1 & $0.03( \pm 0.1)$ & 0 & -- & 0 & -- \\
\hline Photis longicaudata & 363 & $10.1( \pm 8.7)$ & 151 & $5.0( \pm 1.8)$ & 91 & $3.3( \pm 2.4)$ & 267 & $8.3( \pm 5.9)$ \\
\hline Podocerus fissipes & 836 & $18.7( \pm 11.7)$ & 333 & $11.7( \pm 5.0)$ & 493 & $18.3( \pm 12.9)$ & 364 & $11.0( \pm 3.3)$ \\
\hline Podocerus sp. & 122 & $3.3( \pm 2.1)$ & 100 & $3.5( \pm 1.5)$ & 144 & $5.5( \pm 4.3)$ & 160 & $4.9( \pm 1.1)$ \\
\hline Lysianassidae sp. & 1 & $0.1( \pm 0.1)$ & 0 & --- & 0 & --- & 0 & --- \\
\hline Stenothoe sp. & 61 & $1.5( \pm 0.9)$ & 139 & $4.8( \pm 1.5)$ & 10 & $0.4( \pm 0.4)$ & 9 & $0.3( \pm 0.1)$ \\
\hline
\end{tabular}

affecting the survival, growth, and reproduction of the mobile fauna (Roberts et al., 2008). However, more-detailed studies are necessary in order to relate the anthropogenic factor to the differences in the endofauna of sponges on the rocky shores of Ubatuba and São Sebastião.

On the other hand, the wide variations in the densities of the same species of amphipods in the same sponge species may be related to the alterations in the morphological patterns of these hosts, such as texture, size and internal space availability, directly influencing their inhabiting fauna (Palumbi, 1986; Klitgaard, 1995; Koukouras et al., 1996; Loh and Pawlik, 2009; Loh et al., 2012). The wide intraspecific variability in the shape of M. angulosa (Muricy and Hajdu, 2006) may explain the failure of Duarte and Nalesso (1996) to find amphipods associated with this sponge. Another consideration is the possibility of differences in sampling methodology (Klitgaard, 1995; Ribeiro et al., 2003).

The $M$. angulosa biomass showed no temporal variation. The highly structural complexity and extensive internal space of this species made possible the occupation and establishment of a dense amphipod endofauna, as also seen in other studies (Duarte and Nalesso, 1996; Ribeiro et al., 2003). The diameter of the internal water channels of sponges may influence the number and composition of associated individuals 


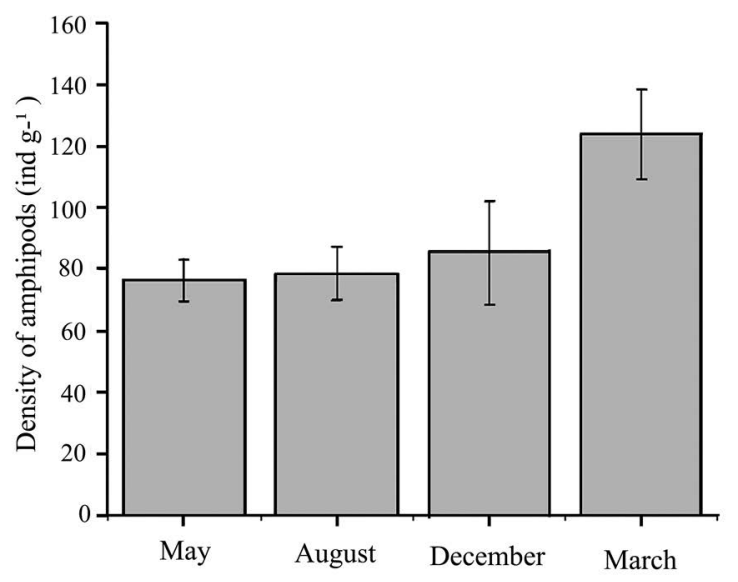

Figure 2. Mean density of gammaridean amphipods (ind $\mathrm{g}^{-1}$ of sponge dry mass) from May/2011 to March/2012, whiskers represent the error bars.

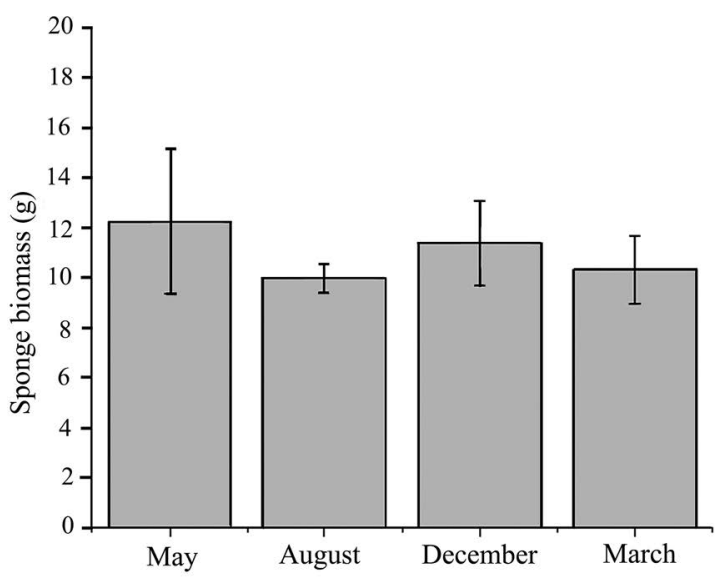

Figure 3. Sponge Mycale angulosa mean biomass (g) collected at Pontal da Cruz Beach, São Sebastião, from May/2011 to March/2012. Whiskers represent the standard deviation.

Table 2. PERMANOVA results for gammaridean amphipod species composition associated with the sponge Mycale angulosa from May/2011 to March/2012. $\mathrm{df}=$ degrees of freedom; MS = mean sum of squares; $\mathrm{F}=$ value by permutation; $\mathrm{P}=$ indicates statistical significance $(P<0.05)$.

\begin{tabular}{lcccc}
\hline Source & df & MS & F & P \\
\hline Es & 3 & 2013.5 & 1.711 & 0.026 \\
Res & 8 & 1176.8 & & \\
Total & 11 & & & \\
\hline
\end{tabular}

(Koukouras et al., 1996). Comparing two different sponge species, Koukouras et al. (1996) observed a larger number of associated individuals for Aplysina aerophoba, which had channels with a mean diameter of $4.1 \mathrm{~mm}$; while Agelas oroides, with channels with a mean diameter of $3.5 \mathrm{~mm}$, contained fewer individuals. Mycale angulosa showed wide variation in the diameters of its oscula and channels (1 to $10 \mathrm{~mm}$ ) (Muricy and Hajdu,
Table 3. Results of the PERMANOVA a posteriori pairwise comparisons test from May/2011 to March/2012, for the gammaridean amphipod fauna associated with the sponge Mycale angulosa $. \mathrm{t}=$ Student's $t$ test $\mathrm{P}=$ indicates statistical significance $(P<0.05)$.

\begin{tabular}{lll}
\hline Groups (Months) & $\mathrm{t}$ & $\mathrm{P}$ (Perm) \\
\hline May, August (2011) & 1.6765 & 0.091 \\
May, December (2011) & 1.1443 & 0.387 \\
May, March (2011/12) & 1.5821 & 0.087 \\
August, December (2011) & 0.9060 & 0.515 \\
August, March (2011/12) & 1.5949 & 0.103 \\
December, March (2011/12) & 1.0392 & 0.383 \\
\hline
\end{tabular}

2006). These small diameters favor the entrance and movement of small-sized organisms such as amphipods. Great abundance of these crustaceans was also observed in congeneric sponges such as Mycale microsigmatosa, an encrusting sponge with oscula $5 \mathrm{~mm}$ in diameter (Ribeiro et al., 2003).

Among the amphipods identified in $M$. angulosa, the species of Corophiidae were the most abundant, with large numbers of Monocorophium sp., Photis longicaudata and Gammaropsis sophiae. The melitid Dulichiella anisochir was also abundant. In contrast, in $M$. microsigmatosa at three sites in Rio de Janeiro State, the most frequent amphipods were Elasmopus pectenicrus (family Melitidae), which was not very common in the present study, and Leucothoe spinicarpa (family Leucothoidae) (Ribeiro et al., 2003), which was not found here. The absence of members of Leucothoidae in the samples may be related to the high abundance of solitary ascidians in the sampling location and in the area as a whole, especially Phallusia nigra (Rocha et al., 2011), a tunicate in which leucothoids preferably shelter (Thiel, 2000).

Even though sponge biomass and the mean total density of amphipods did not show significant variations, the highest mean density occurred in March, that is, in late summer, and the lowest in August, in winter, in parallel with the sponge biomass, which was also lowest in this month. Likewise, Biernbaum (1981) observed in four sponge species that lower densities of amphipod species occurred in the winter.

Although the total density of amphipods did not differ during the sampling period, the density of each species varied considerably in each period so that the dominant species changed in each season. The composition of this amphipod assembly may have been influenced by abiotic 

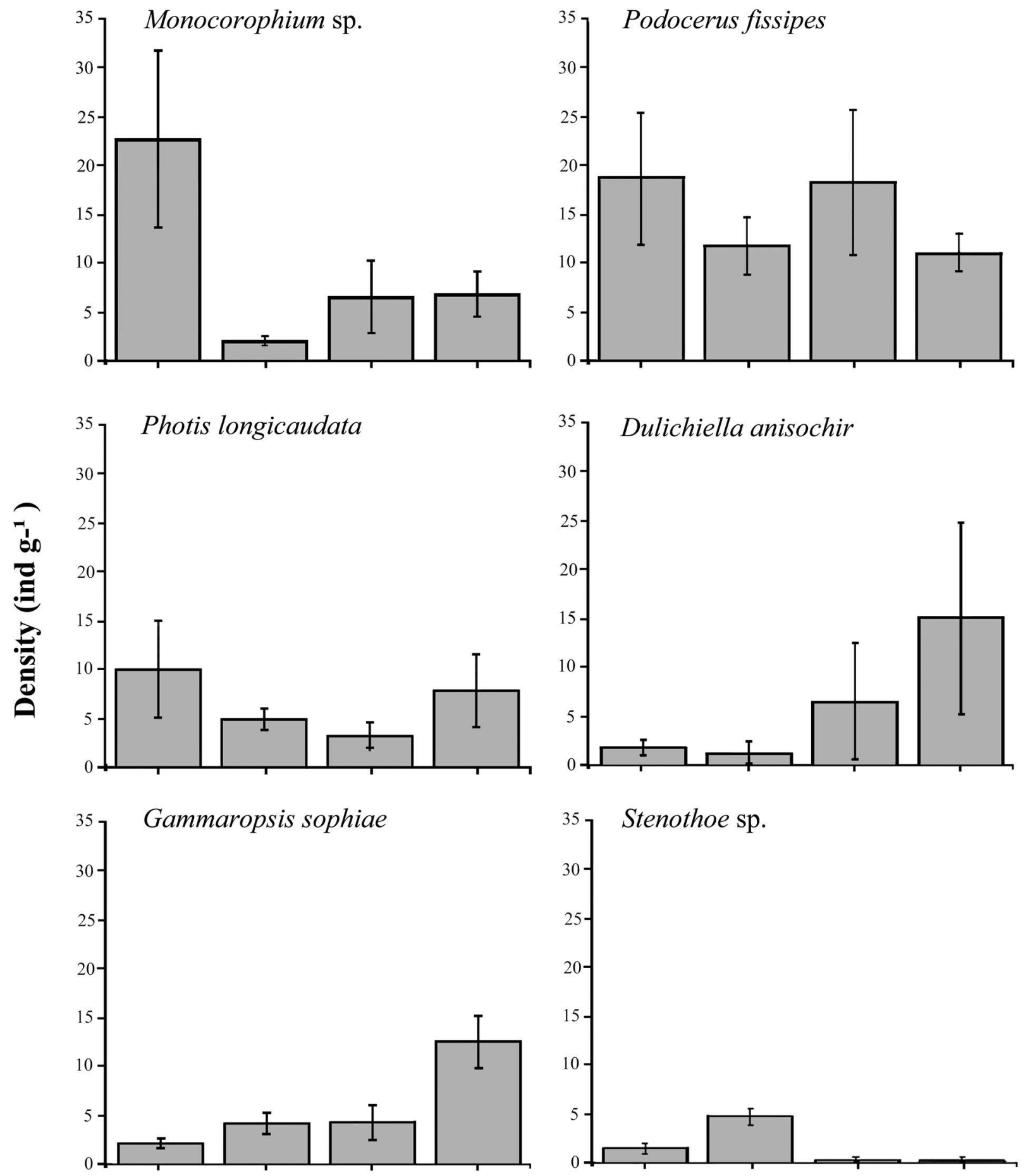

Figure 4. Mean density (ind $\mathrm{g}^{-1}$ of sponge dry mass) of the species of gammaridean amphipods associated with the sponge Mycale angulosa identified through SIMPER, whiskers represent the error bars.

factors (Guerra-García and García-Gómez, 2001; Jacobucci et al., 2009), as well as host-related factors such as biomass and external and internal morphology (Biernbaum, 1981).

Seasonal temperature variations may influence the amphipods associated with biological substrates. Indirectly, temperature may affect the biomass of the substrate (Jacobucci et al., 2009), expanding the available area for occupation and fixation, and increasing the availability of food and shelter, maximizing the survival of the associated fauna. The temperature variations may directly 
Table 4. The gammaridean amphipod species responsible for the differences in assembly composition from May/2011 to March/2012 (SIMPER analysis).

\begin{tabular}{|c|c|c|c|c|c|c|}
\hline Species & May x Aug (2011) & $\begin{array}{c}\text { May x Dec } \\
(2011)\end{array}$ & $\begin{array}{l}\text { Aug x Dec } \\
(2011)\end{array}$ & $\begin{array}{c}\text { May x Mar } \\
(2011 / 12)\end{array}$ & $\begin{array}{l}\text { Aug x Mar } \\
(2011 / 12)\end{array}$ & $\begin{array}{l}\text { Dec x Mar } \\
(2011 / 12)\end{array}$ \\
\hline Monocorophium sp. & 36.6 & 31.7 & 9.8 & 23.2 & 8.1 & 9.0 \\
\hline Podocerus fissipes & 17 & 18.7 & 22.6 & 13.9 & 7.7 & 17.0 \\
\hline Photis longicaudata & 12.9 & 13.5 & 6.9 & 10.0 & 8.7 & 9.9 \\
\hline $\begin{array}{l}\text { Dulichiella } \\
\text { anisochir }\end{array}$ & 0 & 9.2 & 13.7 & 16.0 & 22.4 & 22.8 \\
\hline $\begin{array}{l}\text { Gammaropsis } \\
\text { sophiae }\end{array}$ & 3.2 & 4.5 & 6.8 & 14.7 & 16.4 & 16.4 \\
\hline Stenothoe sp. & 5.6 & 0 & 11.3 & 0 & 8.2 & 0 \\
\hline
\end{tabular}

Resemblance: $\$ 17$ Bray Curtis similary

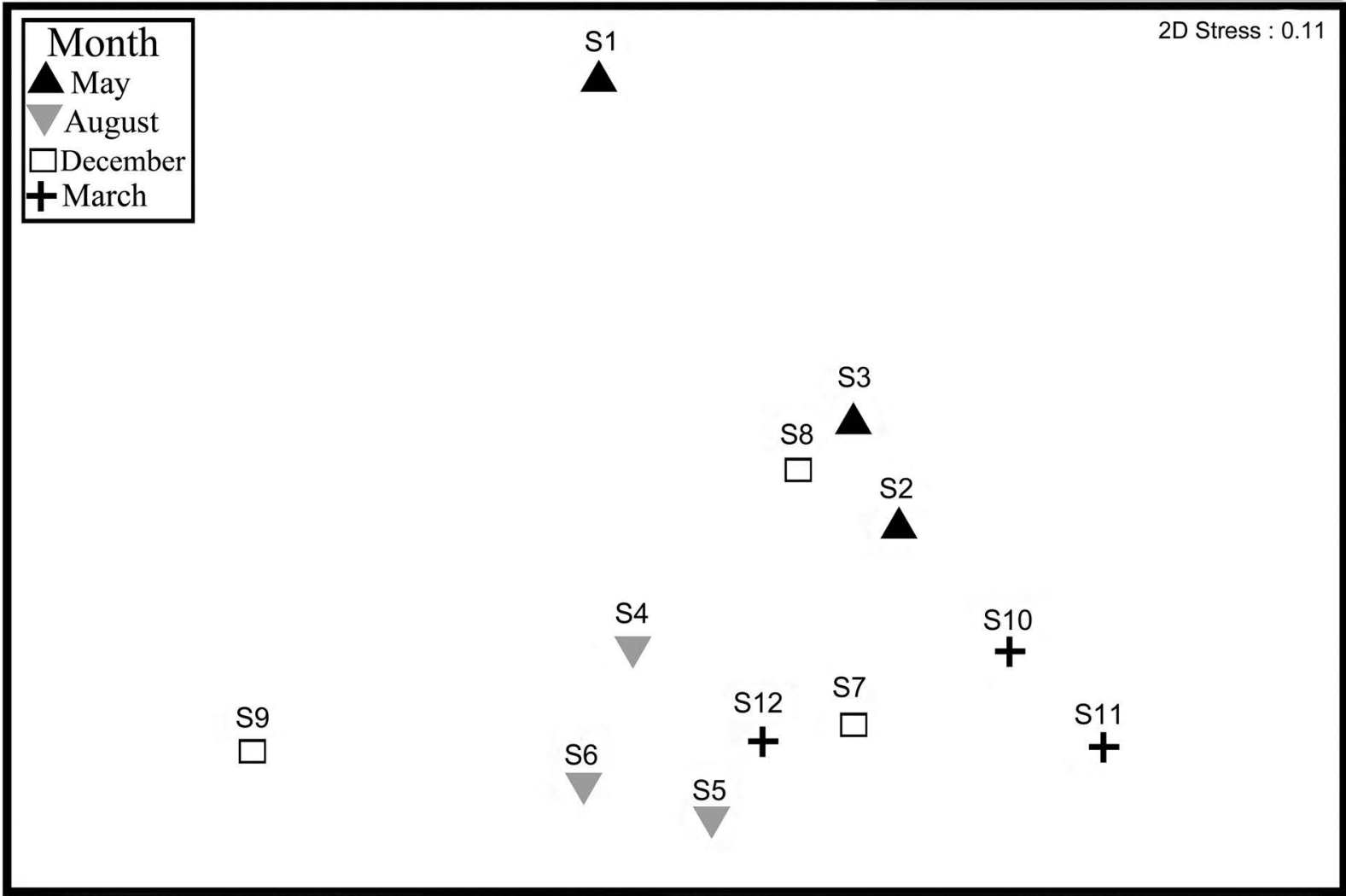

Figure 5. nMDS plots for the gammaridean amphipod density in the sponge Mycale angulosa collected from May/2011 to March/2012.

influence the organisms physiologically (Clarke, 1990), especially their reproduction (Orton, 1920; Sainte-Marie, 1991).

The amphipod fauna found in $M$. angulosa comprised species of detritivores and suspensionfeeders (Biernbaum, 1981; Guerra-García and García-Gómez, 2011; Roberts et al., 2008). The amount and composition of suspended organic matter, in addition to particle deposition, which serve as a food source for these species (Jacobucci et al., 2009; Guerra-García and García-Gómez, 2011), may influence the composition of amphipod assemblages. Similarly, we can draw a parallel with herbivores present in the phytal, which can be favored by the increase of epiphytic algae and the occupied alga itself, because it can also serve as food (Jacobucci et al., 2009).

The coexistence of species with the same feeding habits, not only in $M$. angulosa but in other, similar substrates (Kolding and Fenchel, 1981; Skadesheim, 1984), is probably related to reproductive strategies. As in tropical and subtropical regions amphipods show continuous reproduction (Sainte-Marie, 1991), the alternation in species dominance is related to the life cycle and reproductive strategies of each of them, such as 
incubation period and fecundity (Sutcliffe, 1993; Valério-Berardo and Flynn, 2002; Jacobucci and Leite, 2006). This variation is an efficient strategy to enable amphipods to coexist (Van Dolah and Bird, 1980), avoiding competition for food and space (Skadesheim, 1984).

The different densities of the species that comprised the amphipod assembly in $M$. angulosa over time suggest that the species have different reproductive peaks and strategies. The high densities of Monocorophium sp., D. anisochir and G. sophiae in different months may indicate that these species possess strategies to reduce competition and maximize their survival in $M$. angulosa.

Our study indicated that $M$. angulosa is a favorable microhabitat for several amphipod species. The observed temporal variation in their species composition may be related to variations in the reproductive periods. However, understanding this differentiation requires a temporal evaluation of the population dynamics of each member of the gammaridean assembly, considering aspects of its natural history along with environmental parameters.

\section{ACKNOWLEDGEMENTS}

To Silvana Gomes Leite Siqueira, Edson Vieira Filho, Glauco Machado, Aline Binato Neufeld and Maria Luiza Moraes for helping to identify the species and analyze the data, and to the Fundação de Amparo à Pesquisa do Estado de São Paulo (FAPESP) for funding this research (Proc. No. 2011/17635-3).

\section{REFERENCES}

Abdo, D.A. 2007. Endofauna differences between two temperate marine sponges (Demospongiae; Haplosclerida; Chalinidae) from southwest Australia. Marine Biology, 152: 845-854.

Amaral, A.C.Z.; Migotto, A.E.; Turra, A. and SchaefferNovelli, Y. 2010. Araçá: biodiversidade, impactos e ameaças. Biota Neotropica, 10(1): http://www. biotaneotropica. org.br/v10n1/en/abstract?inventory+ bn01210012010 - ISSN 1676-0603.

Amsler, M.O.; McClintock, J.B.; Amsler, C.D.; Angus, R.A. and Baker, B.J. 2009. An evaluation of spongeassociated amphipods from the Antarctic Peninsula. Antarctic Science, 21: 579-589.

Anderson, M.J. 2001. A new method for non-parametric multivariate analysis of variance. Austral Ecology, 26: 32-46.

Biernbaum, C.K. 1981. Seasonal changes in the amphipod fauna of Microciona prolifera (Ellis \& Solander) (Porifera: Demospongiae) and associated sponges in a shallow saltmarsh creek. Estuaries, 4: 85-96.
Clarke, A. 1990. Temperature and evolution: Southern Ocean cooling and the Antarctic marine fauna. p. 9-22. In: K.R. Kerry and G. Hempel (eds), Antarctic Ecosystems. New York. Springer-Verlag.

Clarke, K.R. and Warwick, R.M. 1994. Change in marine communities: an approach to statistical analysis and interpretation. Plymouth, PRIMER-E, 859p.

Crowe, S.E. and Thomas, J.D. 2002. Abundance and distribution of commensal amphipods from common marine sponges of southeast Florida. p.105-110. In: E. Escobar-Briones and F. Alvarez (eds), Modern Approaches to the Study of Crustacea. New York, Springer-Verlag.

Dalby, J.E. 1996. Nemertean, copepod, and amphipod symbionts of the dimorphic ascidian Pyura stolonifera near Melbourne, Australia: specificities to host morphs and factors affecting prevalences. Marine Biology, 126: 231-243.

Duarte, L. and Nalesso, R. 1996. The sponge Zygomycale parishii (Bowerbank) and its endobiotic fauna. Estuarine, Coastal and Shelf Science, 42: 139-151.

Fiore, C.L. and Jutte, P.C. 2010. Characterization of macrofaunal assemblages associated with sponges and tunicates collected off the southeastern United States. Invertebrate Biology, 129: 105-120.

Frith, D.W. 1976. Animals associated with sponges at North Hayling, Hampshire. Zoological Journal of the Linnean Society, 58: 353-362.

Gochfeld, D.J.; Schlöder, C. and Thacker, R.W. 2007. Sponge community structure and disease prevalence on coral reefs in Bocas del Toro, Panama. Porifera Research: Biodiversity, Innovation, and Sustainability, 28: 335-343.

Guerra-García, J.M. and García-Gómez, J.C. 2011. The spatial distribution of Caprellidea (Crustacea: Amphipoda): a stress bioindicator in Ceuta (North Africa, Gibraltar Area). PSZNI Marine Ecology, 22: 357367.

Huang, J.P.; McClintock, J.B.; Amsler, C.D. and Huang, Y.M. 2008. Mesofauna associated with the marine sponge Amphimedon viridis. Do its physical or chemical attributes provide a prospective refuge from fish predation? Journal of Experimental Marine Biology and Ecology, 362: 95-100.

Jacobucci, G.B. and Leite, F.P.P. 2006. Biologia populacional das espécies de Ampithoidae (Crustacea, Amphipoda) associadas a Sargassum filipendula (Phaeophyta, Fucales) na Praia da Fortaleza, Ubatuba, São Paulo, Brasil. Revista Brasileira de Zoologia, 23: 1207-1216.

Jacobucci, G.B.; Tanaka, M.O. and Leite, F.P.P. 2009. Temporal variation of amphipod assemblages associated with Sargassum filipendula (Phaeophyta) and its epiphytes in a subtropical shore. Aquatic Ecology, 43: 1031-1040.

Klitgaard, A.B. 1995. The fauna associated with outer shelf and upper slope sponges (Porifera, Demospongiae) at the Faroe Islands, northeastern Atlantic. Sarsia, 80: 1-22.

Kolding, S. and Fenchel, T.M. 1981. Patterns of reproduction in different populations of five species of the amphipod genus Gammarus. Oikos, 37: 167-172. 
Koukouras, A.; Russo, A.; Voultsiadou-Koukoura, E.; Arvanitidis, C. and Stefanidou, D. 1996. Macrofauna associated with sponge species of different morphology. Marine Ecology, 17: 569-582.

Loh, T.L.; López-Legentil, S. and Pawlik, J.R. 2012. Phenotypic variability in the Caribbean Orange Icing sponge Mycale laevis (Demospongiae: Poecilosclerida). Hydrobiologia, 687: 205-217.

Loh, T.L. and Pawlik, J.R. 2009. Bitten down to size: fish predation determines growth form of the Caribbean coral reef sponge Mycale laevis. Journal of Experimental Marine Biology and Ecology, 374: 45-50.

Lörz, A.N. and De Broyer, C. 2004. Description of the ecology of a spongicolous lysianassoid amphipod (Crustacea) from Antarctica. Journal of Natural History, 38: 889-899.

Morgado, E.H. and Tanaka, M.O. 2001. The macrofauna associated with the bryozoans Schizoporella unicornis in southeastern Brazil. Scientia Marina, 65: 173-181.

Muricy, G. and Hajdu, E. 2006. Porifera Brasilis: guia de identificação das esponjas marinhas mais comuns do Sudeste do Brasil. Série Livros 17. Rio de Janeiro, Museu Nacional, 104p.

Neves, G. and Omena, E. 2003. Influence of sponge morphology on the composition of the polychaete associated fauna from Rocas Atoll, northeast Brazil. Coral Reefs, 22: 123-129.

Orton, J.H. 1920. Sea-temperature, breeding and distribution in marine animals. Journal of the Marine Biological Association of the United Kingdom (New Series), 12: 339-366.

Oshel, P.E. and Steele, D.H. 1985. Amphipod Paramphithoe hystrix: a micropredator on the sponge Haliclona ventilabrum. Marine Ecology Progress Series, 23: 307-309.

Palumbi, S.R. 1986. How body plans limit acclimation: responses of a demosponge to wave force. Ecology, 67: 208-214.

Poore, A.G.B. and Steinberg, P.D. 1999. Preferenceperformance relationships and effects of host plant choice in an herbivorous marine amphipod. Ecological Monographs, 69: 443-464.

Ribeiro, S.M.; Omena, E.P. and Muricy, G. 2003. Macrofauna associated to Mycale microsigmatosa (Porifera, Demospongiae) in Rio de Janeiro State, SE Brazil. Estuarine, Coastal and Shelf Science, 57: 951-959.

Roberts, D.A.; Johnston, E.L. and Poore, G.B. 2008. Contamination of marine biogenic habitats and effects upon associated epifauna. Marine Pollution Bulletin, 56: 1057-1065.

Rocha, R.M.; Dias, G.M. and Lotufo, T.M.C. 2011. Checklist das ascídias (Tunicata, Ascidiacea) do Estado de São Paulo, Brasil. Biota Neotropica, 11(1a): http:// www. biotaneotropica.org.br/v1 $1 \mathrm{n} 1 \mathrm{a} / \mathrm{en} / \mathrm{abstract}$ ?invent ory+bn0391101a2011 - ISSN 1676-0603.
Sainte-Marie, B. 1991. A review of the reproductive bionomics of aquatic gammaridean amphipods: variation of life history traits with latitude, depth, salinity and superfamily. Hydrobiologia, 223: 189-227.

Schejter, L.; Chiesa, I.L.; Doti, B.L. and Bremec, C. 2012. Mycale (Aegogropila) magellanica (Porifera: Demospongiae) in the southwestern Atlantic Ocean: endobiotic fauna and new distributional information. Scientia Marina, 76: 753-761.

Skadesheim, A. 1984. Coexistence and reproductive adaptations of amphipods: the role of environmental heterogeneity. Oikos, 43: 94-103.

Stofel, C.B.S.; Canton, G.C.; Antunes, L.A.S. and Eutrópio, F.J. 2008. Fauna associada a (sic) esponja Cliona varians (Porífera, Desmoespongiae) (sic). Natureza online, 6(1): 16-18.

Sutcliffe, D.W. 1993. Reproduction in Gammarus (Crustacea: Amphipoda): female strategies. Freshwater Forum, 3: 26-64.

Thiel, M. 2000. Population and reproductive biology of two sibling amphipod species from ascidians and sponges. Marine Biology, 137: 661-674.

Thomas, J.D. and Klebba, K.N. 2007. New species and host associations of commensal leucothoid amphipods from coral reefs in Florida and Belize (Crustacea: Amphipoda). Zootaxa, 1494: 1-44.

Valério-Berardo, M.T. and Flynn, M.N. 2002. Composition and seasonality of an Amphipod community associated to the algae Bryocladia trysigera. Brazilian Journal of Biology, 62: 735-742.

Van Dolah, R.F. and Bird, E. 1980. A comparison of reproductive patterns in epifaunal and infaunal gammaridean amphipods. Estuarine and Coastal Marine Science, 11: 593-604.

Voultsiadou-Koukoura, E.; Koukouras, A. and Eleftheriou, A. 1987. Macrofauna associated with the sponge Verongia aerophoba in the North Aegean Sea. Estuarine, Coastal and Shelf Science, 24: 265-278.

Voultsiadou-Koukoura, E.; Pyrounaki, M.M. and Chintiroglou, C. 2007. The habitat engineering tunicate Microcosmus sabatieri Roule, 1885 and its associated peracarid epifauna. Estuarine, Coastal and Shelf Science, 74: 197-204.

Winfield, I. and Ortiz, M. 2010. Colomastigids (Amphipoda: Gammaridea: Colomastigidae) from the Veracruz Coral Reef System, SW Gulf of Mexico, with a description of two new species associated with sponges. Scientia Marina, 74: 773-782.

Zanardi-Lamardo, E.; Bícego, M.C. and Weber, R.R. 2013. The fate of an oil spill in São Sebastião Channel: A case study. Brazilian Journal of Oceanography, 61: 93-104.

Zar, J.H. 1996. Biostatistical analysis. Third edition. New Jersey, Prentice-Hall, 931p. 